\title{
Financial Flexibility and Tax Incentives: Evidence from Defined Benefit Corporate Pension Plans in Japan
}

\author{
Shingo Goto ${ }^{\mathrm{a}}$ and Noriyoshi Yanase $\mathrm{e}^{\mathrm{b}}$ \\ ${ }^{a}$ Moore School of Business, University of South Carolina, 1795 College St., Columbia, SC 29208, U.S.A. \\ E-mail: shingo.goto@moore.sc.edu \\ ${ }^{\mathrm{b}}$ Faculty of Business Administration, Tokyo Keizai University, 1-7-34 Minami-cho, Kokubunji, \\ Tokyo 1858502, Japan. \\ E-mail: yanase@tku.ac.jp
}

Contrary to the objective of a major corporate pension reform in Japan to enhance retirement income security, and despite the increased relative tax benefits of externally-funded plans, the number of firms that do not sponsor externally-funded defined benefit plans or defined contribution plans has been increasing steadily. We study the common characteristics of firms sponsoring only traditional internally-funded lump sum plans that provide only weak protection of the employees' retirement benefits. We find that smaller firms with higher growth prospects (price-to-book ratios) and a younger workforce are less likely to adopt externally-funded plans and more likely to terminate them when they have one. Firms sponsoring only internally-funded plans tend to exhibit lower profitability than their peers with otherwise similar characteristics. These results suggest that smaller firms with higher growth prospects and a younger workforce tend to have stronger incentives to ensure financial flexibility by providing only weak protection of their employees' retirement benefits.

The Geneva Papers (2013) 38, 753-776. doi:10.1057/gpp.2013.23

Keywords: retirement benefits; Japanese firms; financial flexibility; tax incentives; corporate pension plans; internally-funded lump sum plans

Article submitted 27 December 2012; accepted 14 June 2013; published online October 2013

\section{Introduction}

In the face of a quickly ageing population, establishing a robust corporate pension system is a pressing problem in many developed countries. The problem is especially acute in Japan, where low fertility and high longevity rates accelerate rapid demographic shifts in the workforce. To address this problem, Japanese policymakers took a major step in the early 2000 s to reform the system of employer-sponsored retirement benefit plans. Specifically, two pieces of legislation in 2001 changed the rules governing defined benefit (DB) corporate pension plans and introduced defined contribution (DC) plans. ${ }^{1}$

However, since the reform, the Japanese corporate pension system still faces an important challenge. Contrary to the reform's objective to enhance the protection of employees'

\footnotetext{
${ }^{1}$ With the new rules, the corporate pension system in Japan has become similar to the one in the U.S., at least in the basic structure. See Usuki (2003), Yoshida and Horiba (2003, 2012), McLellan (2004), and Rajnes (2007) for a review.
} 
retirement benefits, the number of firms that do not sponsor externally-funded DB plans or DC plans has been increasing steadily since the early 2000s. The goal of this study is to understand the common characteristics of these firms that provide only weak protection of their employees' retirement benefits.

Historically, employee retirement benefits in Japan started as lump sum severance payments funded by the employers' internal book reserves. Sponsors of these "internally-funded lump sum plans" ${ }^{\prime 2}$ are under no legal obligation to set aside funds to offset their liabilities (i.e. no vesting rules or minimum funding requirements). Nearly all of them are funded internally, and internal funds are not managed as if they were dedicated to funding pensions.

Consequently, internally-funded lump sum plans provide very weak protection of employees' retirement benefits when the sponsoring firms face financial difficulty. Externally-funded pension plans, on the other hand, require the firms to make regular cash contributions to pension plans (separate pension funds) that may only be used for the plan beneficiaries. As such, externally-funded pension plans provide much stronger protection of employees' retirement benefits than internally-funded lump sum plans do.

Therefore, one of the major objectives of the corporate pension reform was to build a wellfunded corporate pension system by promoting a shift from traditional internally-funded lump sum plans to externally-funded pension plans. To prompt the shift, the pension reform completely removed the tax deductible status of internally-funded lump sum plans by $2002 .^{3}$ In theory, this should have made externally-funded pension plans relatively more attractive for employers than internally-funded lump sum plans.

To the contrary, however, the number of Japanese firms that sponsor only internally-funded lump plans-without sponsoring externally-funded DB plans or DC plans - has been increasing steadily since the early 2000s. Despite the reform, the system of employer-sponsored retirement benefits in Japan appears to have been receding to the traditional system of internallyfunded lump sum plans that provide only weak protection of employees' retirement benefits. ${ }^{4}$

Figure 1 illustrates this trend. The share of firms sponsoring only internally-funded lump sum plans without sponsoring externally-funded pension plans has increased steadily from 4.5 per cent in March 2001 to 15.4 per cent in March 2011 among all firms listed on the Tokyo Stock Exchange (TSE). ${ }^{5}$ The increase has been monotonic: economic fluctuations

2 They are officially called "retirement allowance plans" in English. However, we use the term "internally-funded (lump sum) plans" throughout the paper to distinguish them clearly from "externally-funded (pension) plans". We may also call them "internally-funded DB plans" and " externally-funded DB plans" to emphasise that they are parts of DB plans.

${ }^{3}$ Before 2002, Japanese corporate tax laws had allowed them to make periodic tax-deductible "contributions" (allowances) to internally-funded lump sum plans (with some restrictions). Although the reform removed the tax deductible status of internally-funded lump sum plans, firms are still allowed to maintain their internally-funded plans. This is different from the U.S. where firms are never allowed to offer internally-funded employee retirement benefit plans under the Employee Retirement Income Security Act of 1974 (ERISA).

${ }^{4}$ A recent trade article in Investment \& Pensions Asia reports that an increasing number of listed firms have been pulling out of pension plans in recent years: "There has been a noticeable increase in the number of listed companies voluntarily withdrawing from corporate pension fund schemes. Many of them, concerned about their mounting reserve shortages, have been willing to take losses in order to leave the funds. Consultancies helping such companies say that they have seen rising requests seeking voluntary retreats and fundamental overhauls of pension policies, including a shutdown of the funds" ("Japanese listed companies extend exit from corporate pension funds," 30 June 2011).

${ }^{5}$ Firms in financial industries are excluded. Please see the section "Data and variables" for data description. 


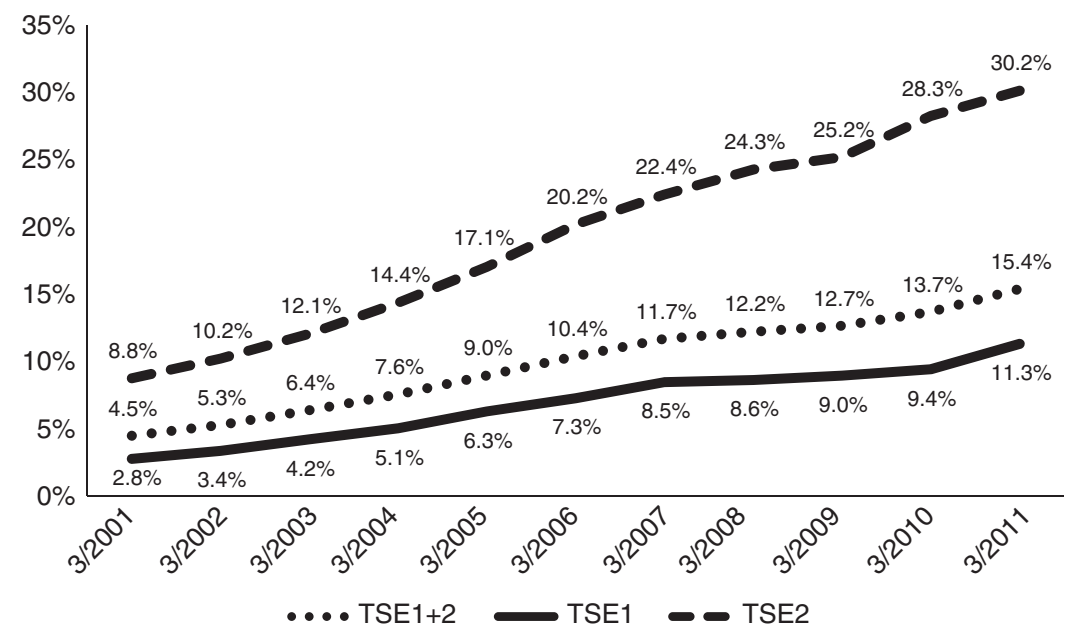

Figure 1. The share of DB plan sponsors without externally-funded pension plans.

The shares are calculated, year by year, as the number of firms sponsoring internally-funded lump sum plans only (without sponsoring externally funded pension plans) over the number of firms sponsoring DB plans (internallyfunded plans or/and externally-sponsored plans). The sample covers Japanese firms listed on the Tokyo Stock Exchange (TSE) that sponsor DB plans (almost all TSE firms sponsor DB plans). Firms with negative equity values and financial firms are excluded from the sample. In the chart, the solid line corresponds to the first section of the TSE (TSE 1, large cap firms) and the dashed line corresponds to the second section of the TSE (TSE 2, mid-cap firms). The dotted line corresponds to both sections.

during the period have had small effects on the trend. The upward trend is more prominent among the firms listed on the second section of TSE (TSE 2, mid-cap firms) than among those listed on the first section (TSE 1, large cap firms). ${ }^{6}$

A natural question is why the number of firms sponsoring externally-funded pension plans has not increased despite the increased tax benefits associated with them. A natural conjecture, drawn from the literature (and common wisdom), is that some firms dislike the loss of financial flexibility from sponsoring externally-funded pension plans. Sponsors of externally-funded pension plans are required to make periodic and irreversible cash contributions to their pension plans, which deteriorate the firms' financial flexibility. ${ }^{7}$ In addition, to protect the employees' retirement benefits, the sponsoring firms of externallyfunded pension plans have to assume the investment risk and actuarial risk associated with the pension plans.

However, taking these risks is not necessarily optimal from the perspective of the shareholder value maximisation. Consequently, it may not be surprising that some firms are unwilling to take on the risk of sponsoring DB pension plans. For example, Peterson ${ }^{8}$ shows that by shifting out of DB pension plans, the sponsoring firms can lower their operating

\footnotetext{
${ }^{6}$ The trend in Figure 1 is not specific to the TSE universe. A similar trend appears in the government statistics that include non-public firms.

${ }^{7}$ Recent studies of U.S. firms demonstrate that DB pension funding requirements put significant constraints on the firms' investment opportunities (e.g. Rauh, 2006, 2009; Franzoni, 2009).

${ }^{8}$ Peterson (1994).
} 
756

leverage and hence transfer risk from shareholders to employees. ${ }^{9}$ Such risk-shifting incentives provide a sensible rationale for firms to avoid externally-funded pension plans.

Furthermore, sponsors of internally-funded lump sum plans typically maintain internal reserves (allowances) for retirement benefits. Since they have no obligations to set aside the reserves from other assets, internally-funded lump sum plans provide the firms with an "inexpensive" means of borrowing from their own employees. ${ }^{10}$ For example, it is possible for the firms to divert their pension assets towards their businesses during a credit crisis. ${ }^{11}$ This feature of internally-funded lump sum plans provides the sponsoring firms with financial flexibility, which should be valuable for firms with limited access to external credit markets.

The choice of retirement benefit plans by Japanese firms provides a useful setting in which we can assess the value of financial flexibility relative to that of tax benefits for firms with different characteristics. The setting is also unique and interesting because both externallyfunded pension plans and internally-funded lump sum plans are allowed to coexist in Japan. The firms would forgo the tax benefits of externally funded pension plans when they attach higher values on financial flexibility than on tax benefits. Some firms, on the other hand, would prefer externally-funded pension plans for the tax benefits, when financial flexibility is not very important for them.

Our empirical findings lend support to this line of reasoning. First, our evidence indicates that smaller firms with higher growth prospects are less likely to adopt externally-funded pension plans and more likely to terminate them if they have one. These firms are more likely to sponsor only internally-funded lump sum plans and forego the tax benefits associated with externally-funded pension plans. Second, our evidence indicates that firms sponsoring only internally-funded lump sum plans tend to have lower expected profitability (as measured by return on assets (ROA) and cash flow on assets (CFOA)), after controlling for conventional predictors including autoregressive effects and industry effects. This finding is consistent with the view that less profitable firms have higher demand for financial flexibility and hence prefer internally-funded lump sum plans to externally-funded pension plans. This finding is also consistent with a view that firms sponsoring externally-funded pension plans have stronger earnings prospects, as firms can benefit from tax deductions only when they generate sufficiently large taxable income. ${ }^{12}$ The direction of causality between plan choice and expected profitability, however, remains unresolved and merits further investigation.

Overall, our evidence lends support to the existence of a trade-off between financial flexibility and tax benefits. It also suggests that firms are willing to give up the tax benefits of externally-funded pension plans when they have concerns about their financial flexibility.

${ }^{9}$ This has prompted an increasing number of U.S. and U.K. firms to shift from DB plans to DC plans. The number of Japanese firms sponsoring DC plans has also increased gradually, but the adoption of DC plans has been slow.

${ }^{10}$ This internal debt is less expensive than external financing for a few reasons: First, employees tend to have more private information about the firm than outside creditors. Second, the internal debt allows the firm to avoid restrictive debt covenants. Third, by making firm managers creditors of the firm, the internal debt can reduce the managers' incentives to expropriate wealth from creditors (Sundaram and Yermack, 2007). Fourth, by imposing a long-run stake in the firm's survival, unfunded or underfunded retirement plans can help curtail opportunistic actions by unionised workers (Ippolito, 1985), though the last point is not apparent for many Japanese firms.

11 "European 'reserve' pensions weather crisis: Aon" (Reuters.com, 25 May 2009).

12 Yoshida and Horiba (2003). 
These firms have incentives to shift risk from shareholders to employees by providing only weak protection of their employees' retirement benefits, since such risk shifting is consistent with the shareholder value maximisation. Thus our study may have an important policy implication. In the current institutional design of the Japanese corporate pension system, it remains a challenge to align some firms' incentives with the policy objective of enhancing the employees' retirement income security.

The rest of the paper proceeds as follows. The next section provides a brief review of employer-sponsored retirement benefit plans in Japan and motivates a set of hypotheses from the extant literature. The subsequent section describes our data. The penultimate section presents and discusses the evidence. The final section concludes. The appendix provides a historical background of Japanese DB plans.

\section{Corporate retirement benefit plans in Japan}

\section{An overview}

In Figure 2, we summarise the structure of employer-sponsored retirement benefit plans in Japan. As is common in many countries, there are DB plans and DC plans in Japan. Japanese DB plans can be classified into two types, depending on how they are funded: (1) externallyfunded pension plans, of which there are three kinds; and (2) internally-funded lump sum plans. Externally-funded pension plans are similar to typical DB pension plans in the U.S.

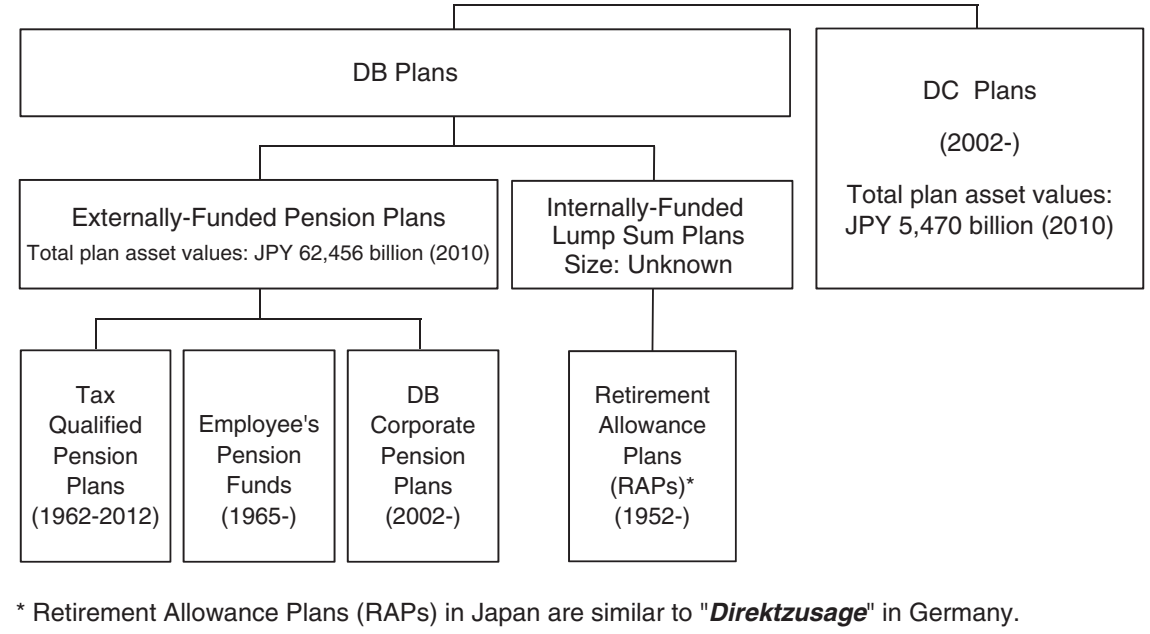

Figure 2. Overview of Japanese retirement plans.

This diagram summarises various types of corporate retirement benefit plans in Japan. Japanese DB plans can be of two kinds (1) externally-funded pension plans (which can be further classified into three plans), and (2) internally-funded lump sum plans. Externally-funded pension plans are similar to typical DB pension plans in the U.S. and other countries. Internally-funded lump sum plans typically make one-time lump sum severance payments rather than periodic pension payments. When we would like to distinguish them from DC plans, we will also call them "Externally-Funded DB Plans" and "Internally-Funded DB Plans". 
Table 1 Total pension asset values in Japan and the U.S.

\begin{tabular}{lcccc}
\hline Fiscal year & \multicolumn{2}{c}{ Japan (JPY in billions) } & & \multicolumn{2}{c}{ United States (USD in millions) } \\
\cline { 2 - 3 } & $D C$ & $D B$ & $D C$ & $D B$ \\
\hline 2002 & 140 & 66,950 & $1,951,596$ & $1,665,657$ \\
2003 & 560 & 69,491 & $2,306,922$ & $1,940,978$ \\
2004 & 1,200 & 65,806 & $2,587,159$ & $2,106,325$ \\
2005 & 2,280 & 75,023 & $2,807,590$ & $2,254,032$ \\
2006 & 3,110 & 76,325 & $3,216,160$ & $2,468,142$ \\
2007 & 3,650 & 69,078 & $3,443,870$ & $2,646,603$ \\
2008 & 3,980 & 57,163 & $2,662,537$ & $2,040,961$ \\
2009 & 4,860 & 63,854 & $3,317,076$ & $2,193,983$ \\
2010 & 5,470 & 62,456 & $3,833,388$ & $2,448,361$ \\
\hline
\end{tabular}

Notes: This table reports total asset values of externally-funded defined benefit (DB) and defined contribution (DC) pension plans in Japan and the United States. In Japan, DC pension plans started in fiscal year (FY) 2002. DB pension plans here refer to externally-funded pension plans and do not include internally-funded lump sum plans. Source: Pension Fund Association of Japan, "Fundamental Resources of Corporate Pension" and U.S. Department of Labor, "Private Pension Plan Bulletin".

and in other countries. internally-funded lump sum plans, on the other hand, do not exist in the U.S. or in the U.K. ${ }^{13}$

While DB plans have a long history in Japan, DC plans took off only recently in FY2002. ${ }^{14}$ The speed of proliferation of Japanese DC plans, however, has been much slower than people had once anticipated. ${ }^{15,16}$ Table 1 summarises the evolution of the total asset size of externally-funded DB plans (we do not observe the size of internally-funded DB plans) and that of DC plans in Japan and the U.S. The total asset size of DC plans has increased steadily from 140 billion yen in FY2002 to 5.47 trillion yen in FY2010. However, the size of DC plans is still very small relative to that of externally-funded DB pension plans (62.5 trillion yen in FY2010). The total size of DC plans is only 8.1 per cent of that of externally-funded DB plans in FY2010. In the U.S., on the other hand, the total asset size of DC plans has been much larger than that of DB plans (USD 3.83 trillion vs 2.45 trillion in FY2010).

While there has been increasing attention to DC plans (and somewhat decreasing attention to DB plans) in the literature, our main discussion of this paper will centre on the difference within DB plans between externally-funded plans and internally-funded plans for two reasons. First, the size of DB plans has been much larger than that of DC plans in Japan. Second, partly due to the sluggish increase of DC plans, it remains difficult to obtain firmlevel data on DC plans. Nevertheless, given the growing importance of DC plans, we extend

13 Japanese internally-funded lump sum plans are similar to "Direktzusage" in Germany, though there are a few differences (see Horiba and Yoshida, 2002).

${ }^{14}$ FY denotes fiscal year. Most Japanese firms have fiscal years ending in March. For example, FY2002 runs from 1 April 2002 to 31 March 2003.

15 McLellan (2004).

${ }^{16}$ A new legislation (the Security Enhancement Act) came into effect in January 2012 to overhaul the system of Japanese DC plans. 
our analysis in the section "Common characteristics of firms sponsoring DC plans only" to examine the common characteristics of firms that sponsor DC plans only (without sponsoring any DB plans) during FY2009 and FY2010. ${ }^{17}$

\section{Hypothesis development}

Our research question is closely related to the pension plan choice problem addressed by Peterson $^{8}$ and Yoshida and Horiba. ${ }^{12,18}$ Peterson considers U.S. firms choosing between externally-funded DB pension plans and DC plans. Owing to the stringent system of mandatory contributions for DB plans, ${ }^{19}$ U.S. firms can reduce their cash flow volatility by converting their DB pension plans to DC plans. Shifts from DB pension plans to DC plans reduce the firms' cash flow risk by lowering their operating leverage, and hence improve their financial flexibility. In the presence of capital market imperfections, the increased financial flexibility can have positive valuation effects, especially for firms that are concerned with financial constraints. Consistent with this argument, Peterson ${ }^{8}$ finds that firms are more likely to choose DC plans over DB pension plans when their cash flows are more volatile and when they have more intangible assets or growth opportunities.

Yoshida and Horiba ${ }^{12}$ study Japanese firms choosing between internally-funded DB plans and externally-funded DB plans for the period between 1975 and 1995, before the corporate pension reform. They hypothesise that firms are more willing to adopt externally-funded plans over internally-funded plans when such adoptions provide larger tax benefits. They show that firms with strong earnings expectations - sufficient to cover tax deductible pension contributions - are more likely to adopt externally-funded DB pension plans than others.

Yoshida and Horiba ${ }^{12}$ emphasise the role of tax benefits in firms' decision to adopt externally-funded DB pension plans, while Peterson ${ }^{8}$ emphasises the value of financial flexibility in firms' decision to disband externally-funded DB pension plans. ${ }^{20}$ Put together, these two arguments represent the trade-off between the incentive to sponsor externallyfunded DB pension plans and the incentive not to sponsor them. We thus consider the following hypothesis:

Hypothesis 1: Firms with higher demand for financial flexibility are more likely to forego possible tax benefits associated with externally-funded DB pension plans.

Another related hypothesis is that firms with strong earnings/cash flow prospects tend to prefer externally-funded DB pension plans to capture tax benefits, while those with weak earnings/cash flow prospects place higher value on the financial flexibility and choose only internally-funded lump sum plans. This implies that a firm's choice of retirement benefit plan

${ }^{17}$ See Yoshida and Horiba (2012) for a more recent and comprehensive study on the factors affecting Japanese firms to adopt DC plans between December 2001 and March 2005.

${ }^{18}$ Other important papers on pension plan choice problems include Stone (1991), and Niehaus and Yu (2005) (Also see Peterson, 1994 and Yoshida and Horiba, 2003, 2012).

${ }^{19}$ In the U.S., the system of mandatory contributions is established by the Employee Retirement Income Security Act of 1974 (ERISA) and strengthened in subsequent legislation, the Pension Protection Act of 2006 (PPA) in particular. Recent researchers show that mandatory contributions exacerbate the under-investment problems of firms with underfunded pension plans (e.g. Rauh, 2006, 2009; Franzoni, 2009).

${ }^{20}$ Under ERISA, internally-funded DB plans are never allowed in the U.S. 
760

is informative about the firm's prospective earnings/cash flows. ${ }^{21}$ This consideration motivates the following hypothesis:

Hypothesis 2: Firms that sponsor only internally-funded lump sum plans tend to have lower expected profitability than their peers with otherwise similar characteristics.

We also note that the "tax advantages" of externally-funded pension plans over internallyfunded lump sum plans are not necessarily obvious. Although periodic contributions to externally-funded plans are fully tax deductible while, following the reform, accruals to internally-funded plans ("retirement allowances") are not, lump sum payments to retirees (from internally-funded plans) are fully tax deductible. Therefore, the relative tax advantage of externally-funded pension plans over internally-funded lump sum plans should depend on the demographics of employees, among others. ${ }^{22}$ For example, the relative tax advantage of externally-funded pension plans over internally-funded lump sum plans should be smaller for firms with an older working population than those with a younger working population. We thus consider the following hypothesis:

Hypothesis 3: Firms with an older workforce tend to prefer internally-funded lump sum plans than their peers with otherwise similar characteristics.

\section{Data and variables}

\section{Data sources and grouping of firms}

We collect accounting data and stock market data from the Astra Manager, a comprehensive database provided by a Japanese financial data vendor Quick Corp. Our sample includes all firms listed on the first and second sections of the TSE whose fiscal years end in March and have positive equity values. ${ }^{23} \mathrm{We}$ exclude firms with negative equity values and those in financial industries. ${ }^{24}$ In the rest of this paper, the subscript $t$ indicates the year of observation. We assume a reporting lag of three months and measure accounting variables at the end of June in each year. Market capitalisation is also measured at the end of June to match the reporting lag of accounting values.

While it is widely known that many Japanese firms sponsor internally-funded lump sum plans for their employees, it is generally difficult to tell which firms sponsor internally-funded

${ }^{21}$ From a different angle, Yoshida and Horiba (2003) show that a firm's decision to adopt externally-funded pension provides a positive signal about the firm's high earnings expectation.

22 According to the model of Horiba and Yoshida (2002), the tax advantage of externally-funded pension plans is likely to be smaller for firms with higher borrowing costs (limited access to credit markets), a lower effective tax rate (lower profitability and/or higher income volatility) and higher administrative costs (smaller plan size). These firms are also likely to have higher demand for financial flexibility.

${ }^{23}$ Most Japanese firms have fiscal years ending in March.

24 The "Accounting Standard for Retirement Benefits", has been implemented since FY2000. This new accounting standard is similar to the Statement of Financial Accounting Standards No. 87 (SFAS 87) in the U. $\mathrm{S}$. Under the new accounting rule, firms sponsoring underfunded DB plans must disclose accrued retirement benefits for employees on their balance sheets and some additional pension-related items (e.g. pension assets, PBO, discount rate) on the footnotes. This has substantially improved the quality of pension accounting data in Japan. 
plans. Not much information is disclosed about internally-funded lump sum plans, making them opaque and mysterious for outside researchers. We therefore take the following approach to group firms.

We start from the fact that, when a firm sponsors externally-funded pension plans, it discloses both pension assets and retirement benefit obligations (e.g. projected benefit obligations (PBO)) in a footnote to its financial statements. On the other hand, a firm sponsoring only internally-funded lump sum plans (without sponsoring externally-funded pension plans) reports retirement benefit obligations (e.g. PBO) but it does not report pension assets. Therefore, the presence of pension assets indicates that the firm sponsors externallyfunded pension plans. A firm that reports retirement benefit obligations, but does not report pension assets is most likely to be a sponsor of internally-funded lump sum plans without externally-funded pension plans. Using this methodology, we are able to classify our sample firms into the following types:

1. "Internal Funding Only": Firms sponsoring only internally-funded DB plans without sponsoring externally-funded pension plans.

2. "With External Funding": Firms sponsoring externally-funded DB plans. Some of them may also sponsor internally-funded plans. ${ }^{25}$

3. "No DB Plans": Firms that do not sponsor any DB plans. They include firms that sponsor DC plans only and those that do not sponsor any retirement plans. We identify firms with "DC Plans Only" and those with "No Retirement Plans" for FY2009 and FY2010.

Table 2 provides a breakdown of Japanese corporate retirement plans. Between March 2001 and March 2011, the number of firms that sponsor only internally-funded plans has increased steadily from 68 to 224. The number of firms that sponsor neither internallyfunded DB plans nor externally-funded plans has also increased from 28 to 125 . Therefore, the number of firms without externally-funded DB plans has increased from 96 to 349. On the other hand, the number of firms sponsoring externally-funded plans have decreased steadily from 1,444 to 1,229 during the same period.

We also drill down firm flows among the three groups and tabulate them in Table 3. We observe that the recent increase in the number of firms in the "Internal Funding Only" group is mainly attributable to net inflows from those that previously had sponsored externallyfunded plans, and to those that newly entered the sample with only internally-funded plans. On the other hand, major fractions of the decline in the number of firms sponsoring externally-funded DB plans can be ascribed to net outflows to the "Internal Funding Only" group and to those firms that exited from the sample (e.g. delisted from the TSE). The number of firms that do not sponsor any DB plans (internally-funded or externally-funded) has been on a steady increase.

\section{Variables}

Hypotheses 1 and 3 involve a few financial characteristics that are associated with (1) the demand for financial flexibility and (2) the relative tax benefits of externally-funded pension plans.

${ }^{25}$ For sponsors of externally-funded pension plans, we cannot tell if they also sponsor internally-funded lump sum plans or not, unfortunately. 
Table 2 Distribution of firms by retirement plan types

\begin{tabular}{|c|c|c|c|c|c|c|c|c|c|c|c|c|c|c|}
\hline \multirow[t]{3}{*}{ Fiscal year ends } & \multicolumn{6}{|c|}{ (A) DB plans } & \multicolumn{6}{|c|}{ (B) No DB plans } & \multirow{2}{*}{\multicolumn{2}{|c|}{$\frac{\text { Total }}{(A)+(B)}$}} \\
\hline & \multicolumn{2}{|c|}{$\begin{array}{l}\text { (1) Internally-funded } \\
\text { lump sum plans only }\end{array}$} & \multicolumn{2}{|c|}{$\begin{array}{l}\text { (2) With externally- } \\
\text { funded pension plans }\end{array}$} & \multicolumn{2}{|c|}{$(1)+(2)$} & \multicolumn{2}{|c|}{$\begin{array}{l}\text { (3) DC plans } \\
\text { only }\end{array}$} & \multicolumn{2}{|c|}{$\begin{array}{l}\text { (4) No retirement } \\
\text { plans }\end{array}$} & \multicolumn{2}{|c|}{$(3)+(4)$} & & \\
\hline & obs. & $\%$ & obs. & $\%$ & $o b s$. & $\%$ & obs. & $\%$ & $o b s$. & $\%$ & obs. & $\%$ & obs. & $\%$ \\
\hline $3 / 2001$ & 68 & 4.4 & 1,444 & 93.8 & 1,512 & 98.2 & NA & - & NA & - & 28 & 1.8 & 1,540 & 100.0 \\
\hline $3 / 2002$ & 81 & 5.2 & 1,446 & 93.4 & 1,527 & 98.6 & NA & - & NA & - & 21 & 1.4 & 1,548 & 100.0 \\
\hline $3 / 2004$ & 117 & 7.3 & 1,427 & 89.0 & 1,544 & 96.3 & NA & - & NA & - & 59 & 3.7 & 1,603 & 100.0 \\
\hline $3 / 2005$ & 140 & 8.5 & 1,419 & 86.6 & 1,559 & 95.2 & NA & - & NA & - & 79 & 4.8 & 1,638 & 100.0 \\
\hline $3 / 2006$ & 162 & 9.8 & 1,394 & 84.2 & 1,556 & 94.0 & NA & - & NA & - & 99 & 6.0 & 1,655 & 100.0 \\
\hline $3 / 2007$ & 183 & 11.0 & 1,380 & 82.7 & 1,563 & 93.6 & NA & - & NA & - & 106 & 6.4 & 1,669 & 100.0 \\
\hline $3 / 2008$ & 189 & 11.4 & 1,356 & 81.8 & 1,545 & 93.2 & NA & - & NA & - & 113 & 6.8 & 1,658 & 100.0 \\
\hline $3 / 2009$ & 192 & 11.8 & 1,323 & 81.1 & 1,515 & 92.8 & NA & - & NA & - & 117 & 7.2 & 1,632 & 100.0 \\
\hline $3 / 2010$ & 203 & 12.7 & 1,277 & 79.8 & 1,480 & 92.5 & 41 & 2.6 & 79 & 4.9 & 120 & 7.5 & 1,600 & 100.0 \\
\hline $3 / 2011$ & 224 & 14.2 & 1,229 & 77.9 & 1,453 & 92.1 & 48 & 3.0 & 77 & 4.9 & 125 & 7.9 & 1,578 & 100.0 \\
\hline Total & 1,657 & & 15,128 & & 16,785 & & 89 & & 156 & & 905 & & 17,690 & 100.0 \\
\hline
\end{tabular}

Notes: This table reports the number of firms by the following retirement plan types: (1) Firms sponsoring internally-funded lump sum plans only; (2) Firms sponsoring externally-funded pension plans (some of them also sponsor internally-funded lump sum plans); (3) Firms sponsoring DC plans only; and (4) Firms that do not sponsor any retirement benefit plans. Our sample consists of Japanese firms listed on the Tokyo Stock Exchange, excluding those with negative equities and those in financial industries. 
Table 3 Detailed breakdown of firm flows among DB plan groups

\begin{tabular}{|c|c|c|c|c|c|c|c|c|c|}
\hline \multirow{2}{*}{$\begin{array}{l}\text { Fiscal year } \\
\text { ends }\end{array}$} & \multirow{2}{*}{$\begin{array}{l}\text { Number at the } \\
\text { beginning of } F Y\end{array}$} & \multicolumn{3}{|c|}{ Outflow } & \multirow{2}{*}{$\begin{array}{l}\text { Remain in internal } \\
\text { funding only }\end{array}$} & \multicolumn{3}{|c|}{ Inflow } & \multirow{2}{*}{$\begin{array}{c}\text { Number at the } \\
\text { end of } F Y\end{array}$} \\
\hline & & $\begin{array}{l}\text { To with external } \\
\text { funding }\end{array}$ & $\begin{array}{l}\text { To no } D B \\
\quad \text { plans }\end{array}$ & $\begin{array}{l}\text { Delisted, } \\
\text { etc. }\end{array}$ & & $\begin{array}{c}\text { From w/ external } \\
\text { funding }\end{array}$ & $\begin{array}{l}\text { From no } D B \\
\text { plans }\end{array}$ & $\begin{array}{c}\text { New } \\
\text { entrants }\end{array}$ & \\
\hline \multicolumn{10}{|c|}{ Panel A: Internal funding only } \\
\hline $3 / 2002$ & 68 & -2 & 0 & -3 & 63 & 8 & 1 & 9 & 81 \\
\hline $3 / 2003$ & 81 & -4 & -2 & -3 & 72 & 13 & 0 & 13 & 98 \\
\hline $3 / 2004$ & 98 & -5 & -2 & -1 & 90 & 8 & 2 & 17 & 117 \\
\hline $3 / 2006$ & 140 & -7 & -2 & -4 & 127 & 18 & 5 & 12 & 162 \\
\hline $3 / 2007$ & 162 & -3 & -3 & -7 & 149 & 17 & 7 & 10 & 183 \\
\hline $3 / 2008$ & 183 & -5 & -1 & -10 & 167 & 10 & 2 & 10 & 189 \\
\hline $3 / 2009$ & 189 & -5 & -4 & -8 & 172 & 10 & 1 & 9 & 192 \\
\hline $3 / 2010$ & 192 & -2 & -4 & -8 & 178 & 17 & 3 & 5 & 203 \\
\hline $3 / 2011$ & 203 & -3 & -1 & -9 & 190 & 30 & 0 & 4 & 224 \\
\hline Total & 1,433 & -43 & -21 & -55 & 1,314 & 149 & 25 & 101 & 1,589 \\
\hline \multirow{2}{*}{$\begin{array}{l}\text { Fiscal year } \\
\text { ends }\end{array}$} & Number at the & \multicolumn{3}{|c|}{ Outflow } & Remain in with external & \multicolumn{3}{|c|}{ Inflow } & Number at the \\
\hline & & $\begin{array}{l}\text { To internal } \\
\text { funding only }\end{array}$ & $\begin{array}{l}\text { To no } D B \\
\text { plans }\end{array}$ & $\begin{array}{l}\text { Delisted, } \\
\text { etc. }\end{array}$ & & $\begin{array}{c}\text { From int. } \\
\text { funding only }\end{array}$ & $\begin{array}{l}\text { From no } D B \\
\text { plans }\end{array}$ & $\begin{array}{c}\text { New } \\
\text { entrants }\end{array}$ & \\
\hline \multicolumn{10}{|c|}{ Panel B: With external funding } \\
\hline $3 / 2002$ & 1,444 & -8 & -3 & -39 & 1,394 & 2 & 13 & 37 & 1,446 \\
\hline $3 / 2003$ & 1,446 & -13 & -8 & -46 & 1,379 & 4 & 0 & 50 & 1,433 \\
\hline $3 / 2004$ & 1,433 & -8 & -8 & -45 & 1,372 & 5 & 3 & 47 & 1,427 \\
\hline $3 / 2005$ & 1,427 & -18 & -8 & -33 & 1,368 & 7 & 1 & 43 & 1,419 \\
\hline $3 / 2006$ & 1,419 & -18 & -6 & -30 & 1,365 & 7 & 1 & 21 & 1,394 \\
\hline $3 / 2007$ & 1,394 & -17 & -2 & -30 & 1,345 & 3 & 3 & 29 & 1,380 \\
\hline $3 / 2008$ & 1,380 & -10 & -4 & -33 & 1,333 & 5 & 1 & 17 & 1,356 \\
\hline $3 / 2009$ & 1,356 & -10 & -3 & -37 & 1,306 & 5 & 3 & 9 & 1,323 \\
\hline
\end{tabular}


Table 3 (continued)

\begin{tabular}{|c|c|c|c|c|c|c|c|c|c|}
\hline \multirow{2}{*}{$\begin{array}{l}\text { Fiscal year } \\
\text { ends }\end{array}$} & \multirow{2}{*}{$\begin{array}{l}\text { Number at the } \\
\text { beginning of } F Y\end{array}$} & \multicolumn{3}{|c|}{ Outflow } & \multirow{2}{*}{$\begin{array}{l}\text { Remain in with external } \\
\text { funding }\end{array}$} & \multicolumn{3}{|c|}{ Inflow } & \multirow{2}{*}{$\begin{array}{c}\text { Number at the } \\
\text { end of FY }\end{array}$} \\
\hline & & $\begin{array}{l}\text { To internal } \\
\text { funding only }\end{array}$ & $\begin{array}{l}\text { To no } D B \quad D \\
\text { plans }\end{array}$ & $\begin{array}{l}\text { Delisted, } \\
\text { etc. }\end{array}$ & & $\begin{array}{c}\text { From int. } \\
\text { funding only }\end{array}$ & $\begin{array}{l}\text { From no } D B \\
\quad \text { plans }\end{array}$ & $\begin{array}{l}\text { New } \\
\text { entrants }\end{array}$ & \\
\hline $3 / 2010$ & 1,323 & -17 & -4 & -39 & 1,263 & 2 & 1 & 11 & 1,277 \\
\hline $3 / 2011$ & 1,277 & -30 & -3 & -35 & 1,209 & 3 & 2 & 15 & 1,229 \\
\hline Total & 13,899 & -149 & -49 & -367 & 13,334 & 43 & 28 & 279 & 13,684 \\
\hline \multirow{2}{*}{$\begin{array}{l}\text { Fiscal year } \\
\text { ends }\end{array}$} & \multirow{2}{*}{$\begin{array}{l}\text { Number at the } \\
\text { beginning of } F Y\end{array}$} & \multicolumn{3}{|c|}{ Outflow } & Remain in no & \multicolumn{3}{|c|}{ Inflow } & Number at the \\
\hline & & $\begin{array}{c}\text { To internal } \\
\text { funding only }\end{array}$ & $\begin{array}{l}\text { To with external } \\
\text { funding }\end{array}$ & $\begin{array}{l}\text { Delisted, } \\
\text { etc. }\end{array}$ & & $\begin{array}{c}\text { From int. } \\
\text { funding only }\end{array}$ & $\begin{array}{l}\text { From w/ external } \\
\text { funding }\end{array}$ & $\begin{array}{c}\text { New } \\
\text { entrants }\end{array}$ & \\
\hline \multicolumn{10}{|c|}{ Panel C: No DB plans } \\
\hline $3 / 2002$ & 28 & -1 & -13 & 0 & 14 & 0 & 3 & 4 & 21 \\
\hline $3 / 2003$ & 21 & 0 & 0 & -2 & 19 & 2 & 8 & 9 & 38 \\
\hline $3 / 2005$ & 59 & -4 & -1 & -1 & 53 & 2 & 8 & 16 & 79 \\
\hline $3 / 2006$ & 79 & -5 & -1 & -3 & 70 & 2 & 6 & 21 & 99 \\
\hline $3 / 2007$ & 99 & -7 & -3 & -6 & 83 & 3 & 2 & 18 & 106 \\
\hline $3 / 2008$ & 106 & -2 & -1 & -3 & 100 & 1 & 4 & 8 & 113 \\
\hline $3 / 2009$ & 113 & -1 & -3 & -4 & 105 & 4 & 3 & 5 & 117 \\
\hline $3 / 2010$ & 117 & -3 & -1 & -5 & 108 & 4 & 4 & 4 & 120 \\
\hline $3 / 2011$ & 120 & 0 & -2 & -2 & 116 & 1 & 3 & 5 & 125 \\
\hline Total & 780 & -25 & -28 & -28 & 699 & 21 & 49 & 108 & 877 \\
\hline
\end{tabular}

Notes: This table reports detailed breakdowns of firm flows among the three groups: (1) Internal funding only; (2) With external funding and (3) No DB plans. Numbers in parentheses indicate outflows. "Internal funding only" indicates that firms sponsoring only internally-funded DB plans without sponsoring externally-funded pension plans. "With external funding" indicates that firms sponsoring externally-funded DB plans. Some of them may also sponsor internally-funded plans. "No DB plans" indicates firms that do not sponsor any DB plans. They include firms that sponsor DC plans only and those that do not sponsor any retirement. 
The demand for financial flexibility is associated with the following financial characteristics: (i) size, (ii) financial leverage, (iii) perceived growth opportunities and (iv) profitability. ${ }^{26}$ First, since smaller firms have more constrained access to external capital markets, we use the natural logarithm of market value of total assets ( $\log (A S S E T))$ as our size proxy. Here, ASSET is the sum of the market value of equities and the book value of total liabilities, both measured at the end of March. Second, because higher financial leverage makes the firm riskier and increases its difficulty in obtaining additional credit, we use the natural logarithm of the ratio of interest-bearing debt to book value of total assets $(\log (L E V E R A G E))$ as our leverage proxy. Third, as firms with greater growth prospects have stronger demand for funding, we use the natural logarithm of the price-tobook ratio $(\log (P B R))$ as our proxy for perceived growth opportunities. The price-to-book ratio (PBR) is measured at the end of June, assuming a 3-month reporting lag for financial statements. Finally, since firms with lower profitability demand more flexible access to funds, we employ ROA, defined by the net profit after tax divided by the book value of total assets in the previous year, as our proxy for the firm's profitability.

The last variable $(R O A)$ can also capture the relative importance of the tax advantage associated with externally-funded pension plans. This is because firms can benefit from the tax benefits only when they have sufficient earnings from which the externally-funded pension plans' premium contributions are deducted. ${ }^{12}$ As additional variables to capture the relative value of tax deduction, we employ the amount of loss carried forward per book value of total assets (in natural logarithm; $\log \left(L O S S_{-}\right.$ $C A R R I E D)$ ) and the average age of its employees (denoted by AVEAGE). Firms with tax loss carryforward tend to pay less corporate income taxes, and hence the tax benefits of externally-funded pension plans have relatively lower value for these firms than other firms. Moreover, the relative tax advantages of externally-funded pension plans over internally-funded lump sum plans are also lower for firms with an older workforce, since these firms are likely to pay more lump sum severance payments that are fully tax deductible.

To test Hypothesis 2, we use ROA and CFOA as profitability measures, where CFOA is the net cash flow from operating activities after tax divided by the book value of total assets in the previous year. The difference between $R O A$ and CFOA is the accruals $(A C C R)$. We include $A C C R$ as a control variable for its known ability to predict future firm performance. ${ }^{27}$

To mitigate the effects of a small number of influential observations, we winsorise these variables at 1 per cent and 99 per cent in each cross section (year by year).

Since firms' financial characteristics exhibit commonality within industries, we employ industry dummies to control for industry-level variation. Our industry dummies are based on TSE's TOPIX-17 industry classification (excluding financial industries).

\footnotetext{
${ }^{26}$ Although these variables are by no means exhaustive, they are representative financial characteristics of firms for which financial flexibility is particularly important. Gamba and Triantis' (2008) model implies that the value of financial flexibility is higher for firms with (i) high growth opportunities, (ii) either low capital or low current profitability; and/or (iii) inflexible production technology.

${ }^{27}$ Sloan (1996).
} 


\section{Evidence}

\section{Summary statistics}

Panel A of Table 4 reports the summary statistics of raw variables. Because some of these variables have extreme values, we log-transform some of the variables and apply winsorisation year by year. Panel B of Table 4 tabulates correlation coefficients among the transformed and winsorised variables.

The asset size (market value) in our pooled sample ranges between 636 million yen and 43.4 trillion yen, with a pooled average of 403.7 billion yen. The market capitalisation of equities ranges between 55 million yen and 28.2 trillion yen, with a pooled average of 179.4 billion yen. Toyota Motor Corporation is the largest company in Japan. The pooled average of PBR is 1.46. The pooled average of ROA is quite low at 1.7 per cent per year. The $75^{\text {th }}$ percentile value is still quite modest at 3.83 per cent, indicating low profitability of Japanese firms during the sample period. The average ratio of accruals to lagged total assets is -3.7 per cent per year. This means that the average CFOA is negative at -2.0 per cent (1.7 per cent-3.7 per cent). The average age of employees ranges between 25.2 years and 62.4 years, with a pooled average of 39.6 years.

\section{Common characteristics of firms sponsoring only internally-funded lump sum plans}

To examine the common characteristics of firms that sponsor only internally-funded lump sum plans (without sponsoring externally-funded pension plans), we employ multiple logit regressions in a pooled sample between FY2000 and FY2010. We define a dummy variable, "Internal_Funding_Only", to indicate firms that sponsor only internally-funded lump sum plans and use it as the dependent variable. Internal_Funding_Only=1 indicates that the firm is in the "Internal Funding Only" group and Internal_Funding_Only=0 is not in the "Internal Funding Only" group.

To inspect the validity of these empirical predictions, we employ logit regressions of the form:

$$
\operatorname{Pr}\left(\text { Internal_Funding_Only } y_{t}=1\right)=F\left(\mathbf{X}_{t}\right),
$$

where $\mathbf{X}_{t}$ is the set of explanatory variables (financial characteristics) observed at $t$ and $F(x)$ is the cumulative logistic distribution. The regression (1) allows us to analyse the common characteristics of firms that sponsor only internally-funded lump sum plans without sponsoring externally-funded pension plans. Our prediction for the coefficients on $\log$ (ASSET), $\log (L E V E R A G E), \log (P B R)$ and ROA from Hypothesis 1 are negative, positive, positive and negative, respectively.

Table 5 reports estimated coefficients of the logit regression (1). Models in columns (1) and (2) do not control for industry effects while models in columns (3) and (4) do. All models include fiscal year dummies to focus on the cross-sectional variation.

Estimated coefficients on $\log (A S S E T)$ are all negative and significant (e.g. -0.941 [ $t=-12.27]$ in the full model (4)), meaning that smaller firms are more likely to sponsor only internally-funded lump sum plans. This is consistent with Hypothesis 1 because smaller firms tend to have more constrained access to external capital markets. We also find that estimated coefficients on $\log (L E V E R A G E)$ are all positive (e.g. 0.136 [ $t=2.08]$ in the full model (4)), indicating that firms with higher financial leverage tend to prefer 
Table 4 Summary statistics and coefficient of correlation (pooled)

\begin{tabular}{lcccccccc}
\hline & Frequency & Mean & Std. & Min. & $25 \%$ & Median & $75 \%$ & Max. \\
\hline Panel A: Summary statistics & (without winsorisation) & & & & & & \\
ASSET (JPY in millions) & 16,764 & 403,665 & $1,489,714$ & 636 & 27,372 & 66,999 & 201,663 & $47,400,000$ \\
LEVERAGE (\%) & 15,465 & 24.47 & 18.18 & 0.00 & 8.89 & 22.01 & 36.67 & 86.43 \\
PBR & 16,777 & 1.46 & 3.71 & 0.02 & 0.70 & 1.03 & 1.59 & 395.49 \\
LOSS_CARRIED (\%) & 16,785 & 2.33 & 10.21 & 0.00 & 0.00 & 0.30 & 1.64 & 378.85 \\
ROA (\%) & 16,330 & 1.70 & 5.62 & -170.22 & 0.43 & 1.82 & 3.83 & 104.51 \\
ACCR (\%) & 16,327 & -3.70 & 6.67 & -157.33 & -6.57 & -3.75 & -1.04 & 139.09 \\
MKTCAP(JPY in millions) & 16,785 & 179,363 & 710,472 & 55 & 10,066 & 26,704 & 96,172 & $28,200,000$ \\
AVEAGE (years) & 16,770 & 39.63 & 3.60 & 25.20 & 37.70 & 39.90 & 41.90 & 62.40 \\
\hline (obs.=15,034) & Log & Log & Log & LOSS_ & ROA & ACCR & Log & AVEAGE \\
& (ASSET) (LEVERAGE) & (PBR) & CARRIED & & & (MKTCAP) & \\
\hline
\end{tabular}

Panel B: Coefficient of correlation (with winsorisation)

$\begin{array}{lrrr}\log (\text { ASSET }) & 1.00 & & \\ \log (\text { LEVERAGE }) & 0.08 & 1.00 & \\ \log (\text { PBR }) & 0.34 & 0.11 & 1.00 \\ \text { LOSS_CARRIED } & -0.14 & 0.10 & 0.1 \\ \text { ROA } & 0.17 & -0.25 & 0.2 \\ \text { ACCR } & -0.05 & -0.07 & -0.0 \\ \text { Log }(\text { MKTCAP }) & 0.93 & -0.10 & 0.4 \\ \text { AVEAGE } & 0.03 & 0.09 & -0.10\end{array}$

$\begin{array}{rrrrr}1.00 & & & & \\ 0.11 & 1.00 & & & \\ 0.21 & -0.35 & 1.00 & & \\ 0.01 & -0.12 & 0.37 & 1.00 & \\ 0.44 & -0.15 & 0.28 & -0.05 & 1.00 \\ 0.10 & 0.07 & -0.12 & 0.02 & -0.05\end{array}$

Notes: Panel A tabulates summary statistics of the raw variables (before log transformation or winsorisation). Panel B reports correlation coefficients among the (transformed) variables that are winsorised at 1 and 99 per $\operatorname{cent} . \log (X)$ indicates the natural logarithm of $X$. The sample universe consists of Japanese firms listed on the Tokyo Stock Exchange that sponsor DB plans (internally funded or/and externally funded), excluding those with negative equities and those in financial industries. Our sample period runs from FY2000 to FY2010. ASSET is the sum of the market value of equities and the book value of total liabilities, both measured at the end of March. LEVERAGE is the ratio of the book value of interest-bearing debts to that of total assets. PBR is the ratio of $M K T C A P$ to the book value of equities, where $M K T C A P$ is the market capitalisation of equities measured at the end of June (assuming a 3-month reporting lag for financial statements). LOSS_CARRIED is the ratio of the value of loss carried forward to the book value of total assets. ACCR is the difference between ROA and CFOA (ACCR=ROA-CFOA), where ROA is the net profit after tax divided by the book value of total assets in the previous year, and $C F O A$ is the net cash flow from operating activities after tax, divided by the book value of total assets in the previous year. AVEAGE is the average age of employees.

internally-funded plans. Furthermore, coefficients on $\log (P B R)$ are all significantly positive (e.g. $0.733[t=5.95]$ ), suggesting that firms with higher perceived growth opportunities are more likely to sponsor only internally-funded lump sum plans. This is also consistent with the notion that growth firms have stronger demand for internal funding.

On the other hand, coefficients on $\log ($ LOSSCARRIED) and ROA are not significantly different from zero, suggesting that taxes have a relatively small effect. We also find that coefficients on $A V E A G E$ are significantly negative, indicating that firms with a younger workforce are more likely to sponsor only internally-funded plans than those with an older workforce, after controlling for firm size, leverage, growth opportunities (as measured by PBR), the tax loss carryforward (as a measure of relative tax benefits), ROA and industries. 
Table 5 Common characteristics of firms sponsoring internally-funded DB plans without sponsoring externally-funded DB plans

\begin{tabular}{|c|c|c|c|c|}
\hline \multirow[t]{2}{*}{$R H S:$} & \multicolumn{4}{|c|}{ Dependent variable: "Internal-Funding Only" } \\
\hline & (1) & (2) & (3) & (4) \\
\hline \multirow[t]{2}{*}{$\log (A S S E T)$} & -0.859 & -0.850 & -0.947 & -0.941 \\
\hline & {$[-12.440]^{* * *}$} & {$[-11.913]^{* * *}$} & {$[-12.607]^{* * *}$} & {$[-12.270]^{* * *}$} \\
\hline \multirow[t]{2}{*}{$\log (L E V E R A G E)$} & 0.191 & 0.230 & 0.113 & 0.136 \\
\hline & {$[2.890]^{* * *}$} & {$[3.452]^{* * *}$} & {$[1.721]^{*}$} & {$[2.078]^{* *}$} \\
\hline \multirow[t]{2}{*}{$\log (P B R)$} & 0.720 & 0.663 & 0.758 & 0.733 \\
\hline & {$[6.402]^{* * *}$} & {$[5.529]^{* * *}$} & {$[6.383]^{* * *}$} & {$[5.953] * * *$} \\
\hline \multirow[t]{2}{*}{ LOSS_CARRIED } & -0.009 & -0.004 & -0.009 & -0.006 \\
\hline & {$[-1.032]$} & {$[-0.464]$} & {$[-0.941]$} & {$[-0.702]$} \\
\hline \multirow[t]{2}{*}{$R O A$} & 0.001 & -0.009 & -0.006 & -0.011 \\
\hline & [0.069] & {$[-0.829]$} & {$[-0.542]$} & {$[-1.088]$} \\
\hline \multirow[t]{2}{*}{$A V E A G E$} & & -0.142 & & -0.089 \\
\hline & & {$[-5.671]^{* * *}$} & & {$[-3.691]^{* * *}$} \\
\hline Industry dummies & No & No & Yes & Yes \\
\hline Year dummies & Yes & Yes & Yes & Yes \\
\hline Observations & 15,065 & 13,696 & 15,065 & 13,696 \\
\hline
\end{tabular}

Notes: This table reports estimated coefficients of logit regressions. The dependent variable, "Internal-Funding Only", is a dummy variable that takes 1 for firms sponsoring internally-funded plans only (without sponsoring externally-funded plans), and 0 for firms sponsoring externally-funded pension plans. The sample period runs from FY2000 to FY2010. Models (1) and (2) include fiscal year dummies and the intercept (not reported), while Models (3) and (4) include fiscal year dummies and TOPIX 17 industry dummies. $t$-statistics based on clustered standard errors (at the firm level) are reported in square brackets below the coefficients. $* * *, * *$ and $*$ indicate significance at the 1,5 and 10 per cent levels, respectively.

\section{Common characteristics of firms that have terminated or newly adopted externally-funded} plans

The logit regression (1) is useful to examine the common characteristics of firms that sponsor internally-funded lump sum plans only without sponsoring externally-funded pension plans. However, the analysis is static and silent about firms' decision to change their retirement plans.

An interesting empirical question is whether and how Japanese firms have changed their retirement plans in response to changes in regulatory environments and shifts in the demographics of the workforce in the recent period. In order to address this question, we examine the common characteristics of firms that have terminated externally-funded pension plans. We also examine the common characteristics of firms that have newly adopted externally-funded pension plans. We implement these analyses with logit regressions of the form:

$$
\operatorname{Pr}\left(w / \text { Ext.Funding }_{t}=0 \mid w / \text { Ext.Funding }_{t-1}=1\right)=F\left(\mathbf{X}_{t}\right), \quad[\text { Termination }]
$$

and

$$
\operatorname{Pr}\left(w / \text { Ext.Funding }_{t}=1 \mid w / \text { Ext.Funding }_{t-1}=0\right)=F\left(\mathbf{X}_{t}\right), \quad[\text { Adoption }]
$$


where $w /$ Ext.Funding ${ }_{t}=1$ indicates that the firm is in the "With External Funding" group in period $t$ and $w / E x t$.Funding ${ }_{t}=0$ indicates that the firm is not in the "With External Funding" group. (w/Ext.Funding ${ }_{t}=0 \mid w /$ Ext.Funding $\left._{t-1}=1\right)$ in the logit regression (2) indicates that the firm sponsored externally-funded plans in period $t-1$, but terminated them in period $t$. (w/Ext.Funding $g_{t}=1 \mid w /$ Ext $_{\text {.Funding }}$ Fu $\left._{-1}=0\right)$ in the logit regression (3) indicates that the firm did not sponsor externally-funded plans in period $t-1$ but adopted them in period $t$. Again, models in columns (1) and (2) do not control for industry effects, while models in columns (3) and (4) do. All models include fiscal year dummies to focus on the cross-sectional variation.

Panel A of Table 6 reports estimated coefficients of the logit regression (2) for firms that have terminated externally-funded pension plans. The sign and significance of each coefficient are consistent with those reported in Table 5, except for the coefficient on $\log ($ LEVERAGE $)$ that is insignificant. ${ }^{28}$ Coefficients on $\log ($ LOSSCARRIED) and ROA are again insignificant. Smaller firms with higher perceived growth opportunities (as measured by higher PBR) are more likely to terminate their externally-funded pension plans, as the coefficient on $\log (P B R)$ is 0.536 [ $t=3.80]$ in the full model (4). Meanwhile, the coefficient on $A V E A G E$ is significantly negative $(-0.054$ [-2.02] in the full model (4)), indicating that firms with a younger workforce are more likely to terminate externally-funded pension plans.

Panel B of Table 6 reports estimated coefficients of the logit regression (3) for firms that have newly adopted externally-funded pension plans. We observe the opposite of Panel A. Larger firms with lower perceived growth opportunities (as measured by lower PBR) and an older workforce are more likely to adopt externally-funded pension plans.

Overall, our results from logit regressions (1)-(3) support Hypothesis 1. Smaller firms with higher growth opportunities, that are likely to have stronger demand for financial flexibility and are more likely to avoid externally-funded pension plans. Larger firms with low growth opportunities, on the other hand, are more likely to sponsor externally-funded pension plans.

Interestingly, ROA and tax loss carryforward are much less important in explaining the choice of retirement plans. Moreover, our results are not fully consistent with Hypothesis 3. Firms with an older workforce tend to prefer externally-funded pension plans than those with a younger workforce, even though larger tax benefits are associated with sponsoring externally-funded pension plans for younger employees.

The evidence suggests that firms with stronger demand for financial flexibility-especially small growth firms with high financial leverage and a younger workforce-are more likely to sponsor internally-funded lump sum plans only and forego the tax benefits associated with externally-funded pension plans. Our evidence further indicates that existing sponsors of externally-funded pension plans are more likely to terminate their externally-funded plans when they have smaller market capitalisation, higher PBR and a younger workforce. On the other hand, firms with larger market capitalisation, lower PBR and an older workforce are more likely to adopt externally-funded pension plans.

${ }^{28}$ One interpretation for this is $\log (L E V E A G E)$ captures firm-level fixed effects in the "level" regression (1), which disappears in the "difference" regression (2) or (3). This interpretation is consistent with the reduction in the coefficient magnitude after the inclusion of industry fixed effects in the "level" regression (1). 
Table 6 Common characteristics of firms that have terminated or newly adopted externally-funded DB plans

RHS: With external funding $\rightarrow$ internal funding only or no DB plans
(1)
(2)
(3)
(4)

\begin{tabular}{lcccc}
\hline Panel A: Characteristics of firms that have terminated externally-funded DB plans & \\
Log $($ ASSET $)$ & -0.620 & -0.602 & -0.649 & -0.643 \\
& {$[-9.459]^{* * *}$} & {$[-9.136]^{* * *}$} & {$[-9.224]^{* * *}$} & {$[-9.152]^{* * *}$} \\
$\log ($ LEVERAGE $)$ & 0.035 & 0.069 & 0.012 & 0.025 \\
& {$[0.482]$} & {$[0.960]$} & {$[0.167]$} & {$[0.350]$} \\
$\log ($ PBR $)$ & 0.549 & 0.500 & 0.542 & 0.536 \\
& {$[4.009]^{* * *}$} & {$[3.623]^{* * *}$} & {$[3.870]^{* * *}$} & {$[3.798]^{* * *}$} \\
LOSS_CARRIED & 0.001 & 0.004 & 0.003 & 0.005 \\
& {$[0.078]$} & {$[0.370]$} & {$[0.247]$} & {$[0.387]$} \\
ROA & -0.013 & -0.015 & -0.016 & -0.015 \\
& {$[-0.568]$} & {$[-0.675]$} & {$[-0.645]$} & {$[-0.618]$} \\
AVEAGE & & -0.106 & & -0.054 \\
& & {$[-4.409]^{* * *}$} & & {$[-2.017]^{* *}$} \\
Industry dummies & No & No & Yes & Yes \\
Year dummies & Yes & 12,563 & 12,568 & Yes \\
Observations & 12,568 & & & 12,563
\end{tabular}

RHS:

Internal funding only or no DB plans $\rightarrow$ with external funding
(1)
(2)
(3)
(4)

Panel B: Characteristics of firms that have newly adopted externally-funded DB plans

\begin{tabular}{lcccc}
$\log ($ ASSET $)$ & 0.567 & 0.568 & 0.659 & 0.652 \\
& {$[4.848]^{* * *}$} & {$[5.031]^{* * *}$} & {$[5.350]^{* * *}$} & {$[5.386]^{* * *}$} \\
$\log ($ LEVERAGE $)$ & -0.080 & -0.117 & -0.001 & -0.024 \\
& {$[-0.762]$} & {$[-1.031]$} & {$[-0.006]$} & {$[-0.191]$} \\
$\log ($ PBR $)$ & -0.497 & -0.399 & -0.600 & -0.589 \\
& {$[-2.161]^{* *}$} & {$[-1.759]^{*}$} & {$[-2.372]^{* *}$} & {$[-2.389]^{* *}$} \\
LOSS_CARRIED & 0.006 & 0.001 & 0.011 & 0.009 \\
& {$[0.312]$} & {$[0.040]$} & {$[0.622]$} & {$[0.447]$} \\
ROA & -0.025 & -0.015 & -0.024 & -0.02 \\
& {$[-0.874]$} & {$[-0.491]$} & {$[-0.807]$} & {$[-0.670]$} \\
AVEAGE & & 0.116 & & 0.065 \\
& & {$[3.848]^{* * *}$} & & {$[1.781]^{*}$} \\
Industry dummies & No & No & Yes & Yes \\
Year dummies & Yes & 1,658 & Yes & Yes \\
Observations & 1,661 & & 1,626 & 1,624 \\
\hline
\end{tabular}

Notes: This table reports estimated coefficients of logit regressions. In Panel A, the dependent variable is a dummy variable that takes 1 for firms switching from the "With External Funding" group to the "Internal Funding Only" group or to the "No DB Plans" group, and 0 for firms that stay in the "With External Funding" group. In Panel B, the dependent variable is a dummy variable that takes 1 for firms switching from the "Internal Funding Only" group or "No DB Plans" group to the "With External Funding" group, and 0 for firms that stay either in the "Internal Funding Only" group or in the "No DB Plans" group. The sample period runs from FY2000 to FY2010. Models (1) and (2) include fiscal year dummies and the intercept (not reported), while Models (3) and (4) include fiscal year dummies and TOPIX 17 industry dummies. $t$-statistics based on clustered standard errors (at the firm level) are reported in square brackets below the coefficients. $* * *, * *$ and $*$ indicate significance at the 1,5 and 10 per cent levels, respectively. 


\section{Internally-funded plans and expected profitability}

Hypothesis 2 implies that the Internal_Funding_Only dummy is negatively associated with the firm's future profitability after controlling for various financial characteristics. To examine if the retirement plan choice can explain the cross-sectional variation in the firm's operating performance measure beyond conventional control variables, we employ multivariate cross-sectional regressions with the procedure of Fama and MacBeth. ${ }^{29}$

A multivariate regression approach is appropriate in the presence of several conditioning variables. For example, operating performance measures such as ROA and CFOA are often persistent and also often exhibit industry-specific fixed effects. Let $y$ denote $R O A$ or $C F O A$. $Z$ represents a set of conditioning variables, including $R O A, A C C R, \log (M K T C A P)$ and $\log$ $(P B R)$ as well as industry dummies. These variables are known to predict the cross-sectional variation of firm profitability.

Then, we estimate cross-sectional regressions of the following form:

$$
y_{t+1}=\text { Internal_Funding_Only } y_{t} \cdot \theta+\mathbf{Z}_{t} \cdot \gamma+\varepsilon_{t+1},
$$

where $y$ and $Z$ are cross-sectional vectors (matrices) that stack individual firms. We reserve $\varepsilon_{t+1}$ to denote error vectors. Both regressions include the set of control variables $\mathbf{Z}_{t}$ ) observed at $t$. Our null hypothesis for each regression is $\theta=0$. Our predictions are $\theta<0$. We estimate the regression (4) in the whole sample and two subsamples sorted by the average age of employees.

Table 7 reports estimated coefficients in cross-sectional predictive regressions of 1-year ahead ROA and CFOA. ROA, ACCR, $\log (M K T C A P)$ and $\log (P B R)$ are all significant in predicting future profitability. After controlling the effects of these predictors and industry dummies, the coefficient on Internal_Funding_Only is significantly negative in ROA regressions in the full sample and in the subsample of firms with an older workforce. The negative coefficient is less significant in $C F O A$ regressions. The negative coefficient on the Internal_Funding_Only is more pronounced among firms with an older workforce, while the coefficient is insignificant among firms with a younger workforce. For example, in the ROA regression, the coefficient on Internal_Funding_Only is -0.445 [ $t=-2.27]$ in the full sample, $-0.999[t=-0.34]$ in the subsample of firms with an older workforce, and -0.140 [ $t=$ -0.62] in the subsample of firms with a younger workforce. This means that, in the full sample, firms sponsoring only internally-funded lump sum plans have expected ROAs that are -0.445 per cent lower than other firms after controlling for the effects of $R O A, A C C R$, $\log (M K T C A P)$ and $\log (P B R)$ as well as industries. The difference in ROA is larger among firms with an older workforce than among firms with a younger workforce.

The negative coefficient on Internal_Funding_Only lends support to Hypothesis 2. It is consistent with a view that firms with weak earnings prospects have high demand for financial flexibility and hence prefer internally-funded lump sum plans to externally-funded pension plans. Firms with strong earnings prospects, on the other hand, have little concerns about their financial flexibility and prefer externally-funded pension plans for the tax benefits. The result is also consistent with a view that a firm's adoption of externally-funded pension plans can signal the firm's high earnings prospects, as firms can benefit from tax deductions only when they generate sufficiently large taxable income. ${ }^{12}$ Yet another view, consistent with the negative coefficient on Internal_Funding_Only, is that lump sum

\footnotetext{
${ }^{29}$ Fama and MacBeth (1973).
} 
Table 7 Fama-MacBeth cross-sectional regressions of 1-year-ahead ROA and CFOA

\begin{tabular}{|c|c|c|c|c|c|c|}
\hline \multirow{4}{*}{$\begin{array}{l}\text { Dependent variable } \\
\text { RHS: }\end{array}$} & \multicolumn{3}{|c|}{$R O A[t+1]$} & \multicolumn{3}{|c|}{$C F O A[t+1]$} \\
\hline & \multirow[t]{2}{*}{ Whole } & \multicolumn{2}{|c|}{ Average age of employees } & \multirow[t]{2}{*}{ Whole } & \multicolumn{2}{|c|}{ Average age of employees } \\
\hline & & High & Low & & High & Low \\
\hline & (1) & (2) & (3) & (4) & (5) & (6) \\
\hline Internal funding only & $\begin{array}{c}-0.445 \\
{[-2.270]^{* *}}\end{array}$ & $\begin{array}{l}-0.999 \\
{[-3.448] * * *}\end{array}$ & $\begin{array}{c}-0.140 \\
{[-0.623]}\end{array}$ & $\begin{array}{l}-0.622 \\
{[-2.011]^{*}}\end{array}$ & $\begin{array}{l}-1.019 \\
{[-2.167]^{*}}\end{array}$ & $\begin{array}{c}-0.339 \\
{[-1.210]}\end{array}$ \\
\hline$R O A$ & $\begin{array}{c}0.564 \\
{[21.499]^{* * *}}\end{array}$ & $\begin{array}{c}0.520 \\
{[18.587]^{* * * *}}\end{array}$ & $\begin{array}{c}0.599 \\
{[15.408]^{* * *}}\end{array}$ & $\begin{array}{c}0.464 \\
{[14.697] * * *}\end{array}$ & $\begin{array}{c}0.469 \\
{[14.531]^{* * *}}\end{array}$ & $\begin{array}{c}0.431 \\
{[11.257]^{* * *}}\end{array}$ \\
\hline$A C C R$ & $\begin{array}{c}-0.125 \\
{[-11.323]^{* * *}}\end{array}$ & $\begin{array}{l}-0.130 \\
{[-8.702]^{* * *} *}\end{array}$ & $\begin{array}{l}-0.114 \\
{[-8.837]^{* * *} *}\end{array}$ & $\begin{array}{c}-0.216 \\
{[-11.375]^{* * *}}\end{array}$ & $\begin{array}{l}-0.189 \\
{[-7.856]^{* * *}}\end{array}$ & $\begin{array}{c}-0.224 \\
{[-11.661]^{* * *}}\end{array}$ \\
\hline $\log (M K T C A P)$ & $\begin{array}{l}0.115 \\
{[2.345]^{* *}}\end{array}$ & $\begin{array}{c}0.118 \\
{[1.672]}\end{array}$ & $\begin{array}{l}0.123 \\
{[2.578]^{* *}}\end{array}$ & $\begin{array}{c}0.321 \\
{[5.789]^{* * *}}\end{array}$ & $\begin{array}{c}0.261 \\
{[6.089]^{* * * *}}\end{array}$ & $\begin{array}{c}0.354 \\
{[4.278]^{* * *}}\end{array}$ \\
\hline $\log (P B R)$ & $\begin{array}{l}0.897 \\
{[5.242]^{* * *}}\end{array}$ & $\begin{array}{l}0.783 \\
{[3.744] * * *}\end{array}$ & $\begin{array}{l}0.968 \\
{[6.544]^{* * *}}\end{array}$ & $\begin{array}{l}0.6 \\
{[2.799]^{* *}}\end{array}$ & $\begin{array}{l}0.550 \\
{[2.603]^{* *}}\end{array}$ & $\begin{array}{l}0.760 \\
{[3.162]^{* *}}\end{array}$ \\
\hline Observations & 14,509 & 7,518 & 7,345 & 14,506 & 7,158 & 7,342 \\
\hline$R$-squared & 0.363 & 0.329 & 0.397 & 0.243 & 0.236 & 0.237 \\
\hline
\end{tabular}

Notes: This table reports estimated coefficients for Fama-MacBeth OLS cross-sectional regressions of 1-year-ahead $R O A$ and CFOA (as indicated by $[t+1]$ ), for the whole sample and for two subsamples sorted by the average age of employees (above median vs median or below). "Internal-Funding Only" is a dummy variable that takes 1 for firms sponsoring internally-funded plans only (without sponsoring externally-funded plans), and 0 for firms sponsoring externally-funded pension plans. The sample period runs from FY2001 to FY2010 for the dependent variables (FY2000-FY2009 for the predicting variables). The regression includes TOPIX 17 industry dummies. $t$-statistics are reported in square brackets below the coefficients. $* * * * *$ and $*$ indicate significance at the 1,5 and 10 per cent levels, respectively.

severance payments lower the profitability of firms sponsoring internally-funded lump sum plans. On appearance, this view is consistent with the subsample result, as firms with an older workforce pay larger lump sum retirement benefits. However, it is not clear why forward-looking variables such as $\log (M K T C A P)$ and $\log (P B R)$ do not account for this effect. While there are many possible explanations for the negative coefficient on Internal_Funding_Only, the direction of causality between the DB plan choice and expected profitability remains unresolved and merits further investigation.

\section{Common characteristics of firms sponsoring DC plans only}

Although DC plans are still much smaller in magnitude than DB plans in Japan, there is no question about the growing importance of DC plans in employer-sponsored retirement benefit plans. We therefore extend the logit regression (1) to examine the common characteristics of firms sponsoring DC plans only (without sponsoring any DB plans). Owing to the difficulty of collecting firm-level DC plan data, our analysis is limited to 2 years, FY2009 ad FY2010. ${ }^{30}$

${ }^{30}$ Please see Yoshida and Horiba (2012) for a recent study of Japanese firms that have adopted DC plans between $12 / 2001$ and 3/2005. They find that larger firms with lower DB pension underfunding are more likely to adopt DC plans. 
Table 8 Common characteristics of firms sponsoring DC plans only (without sponsoring any DB plans)

\begin{tabular}{lcccc}
\hline & \multicolumn{4}{c}{ Dependent variable: “DC Only" } \\
\hline RHS: & $(1)$ & $(2)$ & $(3)$ & $(4)$ \\
\hline Log $($ ASSET $)$ & -0.447 & -0.282 & -0.294 & -0.237 \\
& {$[-5.192]^{* * *}$} & {$[-2.840]^{* * *}$} & {$[-3.040]^{* * *}$} & {$[-2.273]^{* *}$} \\
Log(LEVERAGE $)$ & 0.077 & 0.089 & 0.039 & 0.034 \\
& {$[0.452]$} & {$[0.533]$} & {$[0.234]$} & {$[0.201]$} \\
Log(PBR $)$ & 0.745 & 0.401 & 0.427 & 0.325 \\
& {$[2.318]^{* *}$} & {$[1.281]$} & {$[1.373]$} & {$[1.062]$} \\
LOSS_CARRIED & -0.011 & -0.002 & -0.005 & -0.001 \\
& {$[-0.605]$} & {$[-0.120]$} & {$[-0.324]$} & {$[-0.100]$} \\
ROA & 0.088 & 0.064 & 0.085 & 0.073 \\
& {$[2.491]^{* *}$} & {$[2.007]^{* *}$} & {$[2.513]^{* *}$} & {$[2.233]^{* *}$} \\
AVEAGE & & -0.227 & & -0.092 \\
& & {$[-3.221]^{* * *}$} & & {$[-1.390]$} \\
Industry dummies & No & No & Yes & Yes \\
Year dummies & Yes & Yes & Yes & Yes \\
Observations & 2,778 & 2,776 & 1,816 & 1,816 \\
\hline
\end{tabular}

Notes: This table reports estimated coefficients of logit regressions. The dependent variable, "DC Only", is a dummy variable that takes 1 for firms sponsoring DC plans only (without sponsoring any DB plans), and 0 for firms sponsoring DB plans (internally funded or/and externally funded). The sample period covers FY2009 and FY2010. Models (1) and (2) include fiscal year dummies and the intercept (not reported), while Models (3) and (4) include fiscal year dummies and TOPIX 17 industry dummies. $t$-statistics based on clustered standard errors (at the firm level) are reported in square brackets below the coefficients. ${ }^{* *}, * *$ and $*$ indicate significance at the 1,5 and 10 per cent levels, respectively.

In addition, controlling for industries reduces the sample size by about one-third because 9 out of 17 industries have no firms sponsoring DC plans only in our sample.

Estimated coefficients in Table 8 suggest that smaller firms with higher ROA and a younger workforce are more likely to sponsor DC plans only (without sponsoring DB plans). However, due to the limited sample, we refrain from drawing strong conclusions from this exercise.

\section{Conclusion}

With an aim to enhance the retirement income security of corporate employees, Japanese policymakers introduced a major corporate pension reform in the early 2000s. Contrary to the reform's objective to enhance the protection of the employees' retirement benefits, the number of firms that sponsor neither externally-funded DB plans nor DC plans has been increasing steadily since the early 2000s. On the other hand, the number of firms sponsoring externally-funded DB plans has been on a decreasing trend despite the increased relative tax benefits associated with them, and the growth of DC plans has been slower than once anticipated.

To understand the causes of this phenomenon, we study the common characteristics of firms that provide only weak protection of their employees' retirement benefits. We pay particular attention to firms that sponsor traditional internally-funded lump sum plans but do not sponsor any externally-funded pension plans. 
Motivated from the trade-off between tax benefits and financial flexibility, we hypothesise that firms with stronger demand for financial flexibility are more likely to sponsor only internallyfunded lump sum plans and forego the tax benefits associated with externally-funded pension plans. Our evidence indicates that smaller firms with higher financial leverage, higher growth prospects (as measured by PBR) and a younger workforce are more likely to sponsor internallyfunded lump sum plans without sponsoring externally-funded pension plans. These firms tend to have lower expected profitability than their peers with similar characteristics. Our evidence also indicates that smaller firms with higher growth prospects and a younger workforce are less likely to adopt externally-funded pension plans and more likely to terminate them.

For firms with strong demand for financial flexibility, tax benefits do not provide sufficient incentives for adopting and sustaining externally-funded plans. Rather, their incentives to shift risk from shareholders to the employees dominate. This suggests that the current institutional design of the Japanese corporate pension system faces a major challenge: firms' incentives are not aligned well with the policy objective to enhance the retirement income security of corporate employees.

\section{Acknowledgements}

We are grateful to the journal's co-editors and two anonymous referees for constructive suggestions. Special thanks go to Gregory Niehaus and Takefumi Ueno for helpful comments and discussions throughout the project. The paper also benefits from helpful comments by seminar participants at the Asia Pacific Risk and Insurance Association, the European Accounting Association, the Japanese Society of Insurance Science and Hitotsubashi University. This research is supported in part by the Postal Life Insurance Foundation of Japan (Kampo Zaidan).

\section{References}

Fama, E.F. and MacBeth, J.D. (1973) 'Risk, return, and equilibrium: Empirical tests', Journal of Political Economy 81(3): 607-636.

Franzoni, F. (2009) 'Underinvestment vs. overinvestment: Evidence from price reactions to pension contributions', Journal of Financial Economics 92(3): 491-518.

Gamba, A. and Triantis, A. (2008) 'The value of financial flexibility', The Journal of Finance 63(5): 2263-2296.

Horiba, Y. and Yoshida, K. (2002) 'Determinants of Japanese corporate pension coverage', Journal of Economics and Business 54(5): 537-555.

Ippolito, R.A. (1985) 'The labor contract and true economic pension liabilities', The American Economic Review 75(5): 1031-1043.

McLellan Ingmanson, S. (2004) Corporate pension reform in Japan: Big Bang or Big Bust? Pension Research Council Working Paper No. 2004-05, The Wharton School, University of Pennsylvania, Philadelphia, PA.

Niehaus, G. and Yu, T. (2005) 'Cash-balance plan conversions: Evidence on excise taxes and implicit contracts', The Journal of Risk and Insurance 72(2): 321-352.

Peterson, M.A. (1994) 'Cash flow variability and firm's pension choice: A role for operating leverage', Journal of Financial Economics 36(3): 361-383.

Rajnes, D. (2007) 'The evolution of Japanese employer-sponsored retirement plans', Social Security Bulletin 67(3): 89-104.

Rauh, J.D. (2006) 'Investment and financing constraints: Evidence from the funding of corporate pension plans', The Journal of Finance 61(1): 33-71.

Rauh, J.D. (2009) 'Risk shifting versus risk management: Investment policy in corporate pension plans', The Review of Financial Studies 22(7): 2687-2733. 
Sloan, R.G. (1996) 'Do stock prices fully reflect the information in accruals and cash flows about future earnings?' The Accounting Review 71(3): 289-315.

Stone, M. (1991) 'Firm financial stress and pension plan continuation/replacement decisions', Journal of Accounting and Public Policy 10(3): 175-206.

Sundaram, R.K. and Yermack, D.L. (2007) 'Pay me later: Inside debt and its role in managerial compensation', The Journal of Finance 62(4): 1551-1588.

Usuki, M. (2003) Recent changes to retirement benefits in Japan, and relative public policy issues, Discussion Paper 135, Institute of Economic Research, Hitotsubashi University, Tokyo, Japan.

Yoshida, K. and Horiba, Y. (2003) 'Japanese corporate pension plans and the impact on stock prices', Journal of Risk and Insurance 70(2): 249-268.

Yoshida, K. and Horiba, Y. (2012) 'Determinants of defined-contribution Japanese corporate pension coverage', Japanese Accounting Review 2: 33-47.

\section{Appendix}

\section{A brief history of $D B$ retirement plans in Japan}

\section{Internally-funded lump sum plans}

Historically, Japanese employers make lump sum severance payments to their employees when they retire or leave, no matter whether their reasons for leaving are voluntary (e.g. resignation) or involuntary (e.g. death, dismissal or reaching the mandatory retirement age). The tax code in 1952 provided tax incentives for establishing retirement allowance plans to prepare for the lump sum severance payments, which promoted firms to make periodic tax-favoured contributions to the internally-funded lump sum plans. Since internally-funded lump sum plans are funded by book reserves rather than externally accumulated assets, the plans often fail to secure sufficient funds for the benefit payments.

When the Tax Reform Law of 1952 legalised internally-funded lump sum plans, internally-funded lump sum plans were allowed to set up a tax-qualified account earmarked for meeting retirement benefits for employees under the law. The account was fully tax deductible. Although Japanese tax laws only had provisions for the internally-funded lump sum plans and do not allow a tax deduction for annuity benefit plans before 1962, the law reform of 1962 introduced voluntary tax-qualified pension plans which have an advance funding system. "Tax qualified pension plans" were introduced in 1962 based on the occupational pension model of the pre-ERISA era in the U.S. The tax qualified plans are regulated by the Ministry of Finance. Firms with voluntary tax qualified pension plans must establish out-of-house pension reserves. The amount of contribution is 100 per cent tax deductible. The corporate pension reform aimed to promote a shift from this traditional system of internally-funded lump sum plans to a system of externally-funded pension plans.

To facilitate this, the amount of tax deduction of internally-funded lump sum plans was limited to 50 per cent ("tax deduction rate") of total benefits by revised legislation in 1956. Japan gradually removed the tax deductible status of internally-funded lump sum plans. In 1980, the tax deduction rate was limited to 40 per cent, and revised to 20 per cent in 1998 . Two pieces of legislation in 2001 changed the rules governing DB plans and introduced DC plans. After the reform of 2001, firms are forbidden from accumulating a book reserve from 2002 onwards. 


\section{Externally-funded pension plans}

There are three types of externally-funded pension plans: Tax-qualified pension plans, employee's pension funds and DB corporate pension plans. The tax-qualified pension plans were introduced in 1962, regulated by the Ministry of Finance. Firms with voluntary taxqualified pension plans must establish out-of-house pension reserves. The amount of contribution is 100 per cent tax deductible in the DB plan. The corporate pension reform aimed to promote a shift from this traditional system of internally-funded plans to a system of externally-funded pension plans. Employees' pension funds were established in 1966 to provide sufficient financial security to employees in the private DB pension sector. Employees' pension funds must be established as a legal entity that is independent from the sponsoring firm, and pension assets must be held outside the sponsoring firms. Their tax treatments are virtually the same as those of the tax qualified pension plans. The employees' pension funds are regulated by the Ministry of Health, Labour and Welfare, not by the Ministry of Finance.

Until 2001, Japanese employers generally used three types of DB-type retirement plans: internally-funded lump sum plans and two externally-funded pension plans (tax-qualified pension plans and employees' pension funds). Then, the Japanese externally-funded pension plans underwent substantial changes in the early 2000s. First, the Defined Benefit Corporate Pension Law of 2001 ("DBCP law") established defined benefit corporate pension plans. The law aims to unify the regulations and tax provisions of different externally-funded pension plans, and to enhance the retirement income security of plan participants. In addition, all externally-funded pension plans will be under the single regulatory control of the Ministry of Health, Labour and Welfare, as the tax-qualified pension plans that had been regulated by the Ministry of Finance were scheduled to be terminated by 31 March 2012.

\section{About the Authors}

Shingo Goto is a clinical Associate Professor of Finance at the Moore School of Business, University of South Carolina in the United States.

Noriyoshi Yanase is Professor of Insurance and Risk management in the Faculty of Business Administration at Tokyo Keizai University in Japan. He serves as a board member of the Asia-Pacific Risk and Insurance Association (APRIA). Professor Yanase is also a research fellow of the Institute of Strategic Solutions for Pension Management in Japan. 